\title{
Analisis Kebutuhan Sumber Daya Manusia Petugas Rekam Medis Dengan Menggunakan Metode Analisis Beban Kerja Kesehatan (ABK-Kes)
}

\section{Analysis of Human Resources Needs For Medical Record Officers Using The Health Workload Analysis Method (ABK-Kes)}

\author{
Clarissa Amalia Putri ${ }^{1}$, Meira Hidayati ${ }^{2}$ \\ Program Studi Rekam Medis dan Informasi Kesehatan \\ Politeknik Piksi Ganesha \\ email : caputri@piksi.co.id ;meira.hidayati@piksi.co.id \\ Jl. Jend. Gatot Subroto No.301, Bandung
}

\begin{abstract}
ABSTRAK
Sumber Daya Manusia adalah bagian terpenting dan vital dalam sebuah organisasi. memberikan pelayanan yang bermutu maka dibutuhkan Sumber Daya Manusia Perekam Medis yang cukup, karena Klinik Utama Mutiara Cikutra hanya memiliki satu perekam medis saja maka hal ini bagus untuk dijadikan penelitian. Berdasarkan hasil wawancara, kunjungan pasien di Klinik Utama Mutiara Cikutra Bandung pada periode April 2020 April 2021 sebanyak 47.139 pasien. Tujuan dari penelitian ini untuk menghitung kebutuhan sumber daya manusia rekam medis dengan menggunakan metode analisis beban kerja kesehatan (ABK-Kes). Penelitian ini menggunakan jenis penelitian deskriptif dengan pendekatan kualitatif dan jenis rancangannya merupakan fenomenologi. Pengumpulan data dengan menggunakan Teknik wawancara kepada petugas rekam medis, studi dokumen dan observasi di Klinik Utama Mutiara Cikutra Bandung pada bulan April - Juni 2021. Berdasarkan data yang dikumpulkan setelah diolah menggunakan ABK-Kes diperoleh hasil bahwa jumlah pegawai hanya satu orang dan terdapat kekurangan pegawai Rekam Medis dan harus melakukan penambahan pegawai baru bagian rekam medis sebanyak empat orang.
\end{abstract}

Kata kunci : Analisis Beban Kerja, Rekam Medis, Sumber Daya Manusia

\section{ABSTRACT}

Human Resources is the most vital part of an organization. To provide quality services, sufficient Medical Recorder Human Resources are needed, because Mutiara Cikutra Clinic only has one medical recorder, this is good for research. Based on the results of interviews, patient visits at Mutiara Cikutra Clinic Bandung in the period April 2020 April 2021 were 47,139 patients. The purpose of this study was to calculate the need for medical record human resources using the Health Workload Analysis (ABK-Kes) method. This study uses a descriptive type of research with a qualitative approach and the type of design is phenomenological. Data collection using interview techniques to medical record officers, document studies, and observations at the Mutiara Cikutra Clinic, Bandung in April - June 2021. Based on the data collected after being processed using $A B K$-Kes, it was found that the number of employees was only one person and there was a shortage of Record employees. Medical staff and must add four new employees to the medical record section.

Keywords: Human Resources, Medical Record, Woarkload Analysis 


\section{PENDAHULUAN}

Klinik harus memiliki sumber daya manusia yang berkualitas baik di bidang teknis maupun pendistribusian, klinik mempunyai tanggung jawab terhadap mutu pelayanan diantaranya adalah menambah Sumber Daya Manusia yang mempunyai kompetensi dan jumlah yang cukup untuk memenuhi kriteria pelayanan kesehatan di klinik. Berdasarkan Undang - Undang Republik Indonesia No.36 tahun 2014 tentang tenaga kesehatan. Tenaga kesehatan adalah setiap orang yang mengabdikan diri dalam bidang kesehatan serta memiliki pengetahuan atau keterampilan melalui Pendidikan dibidang kesehatan untuk jenis tertentu memerlukan kewenangan untuk melakukan upaya kesehatan. Menurut (Situmorang, 2017) yaitu Sumber Daya Manusia adalah asset yang sangat berharga dalam organisasi / perusahaan. Tanpa manusia maka sumber daya perusahaan tidak bisa menciptakan laba atau menaikkan nilainya sendiri.

Berdasarkan hasil observasi dan wawancara kepada tenaga Rekam Medis di Klinik Utama Mutiara Cikutra pada bulan April - Juni 2021. Pada saat ini jumlah sumber daya manusia kesehatan (SDMK) yang tersedia di unit kerja rekam medis (UKRM) di Klinik Utama Mutiara Cikutra hanya berjumlah satu orang. Total kunjungan pasien pada periode April 2020 - April 2021 sebanyak 47.139 pasien dengan rata - rata kunjungan pasien perhari sebanyak 129 pasien perhari. Karena kurang nya sumber daya manusia kesehatan (SDMK) di Unit Kerja Rekam Medis di Klinik Utama Mutiara Cikutra maka petugas Rekam Medis tersebut di bantu oleh pegawai lain yaitu terdiri dari 3 orang tim admin yang di tempatkan di bagian pendaftaran pasien. Dengan kurangnya sumber daya manusia kesehatan (SDMK) saat ini upaya yang dilakukan adalah mendayagunakan tenaga yang ada untuk membantu mengurangi beban kerja petugas rekam medis tersebut.

Berdasarkan hasil perhitungan yang telah dilakukan, jumlah tenaga rekam medis dengan jumlah pasien dan beban kerja tidak sebanding sehingga membuat petugas rekam medis tersebut kadang kewalahan melakukan pekerjaan nya.

\section{METODE}

Penelitian ini menggunakan jenis penelitian deskriptif dengan pendekatan kualitatif dan jenis rancangannya merupakan fenomenologi yaitu mendeskripsikan keadaan atau beberapa fenomena yang terjadi dengan melakukan perencanaan kebutuhan sumber daya manusia (SDM) pada pelayanan unit kerja rekam medis di Klinik Utama Mutiara Cikutra. Subjek penelitiannya yaitu petugas rekam medis di Klinik Utama Mutiara Cikutra yang hanya berjumlah 1 (satu) orang. Penelitian ini dilakukan di Klinik 
Clarissa Amalia Putri, Meira Hidayati : Analisis Kebutuhan Sumber Daya Manusia Petugas Rekam ....

Utama Mutiara Cikutra yang berlokasi di Blk. A-B Jl. Cikutra No. 115, Cikutra, Kec. Cibenying Kidul Kota Bandung. Waktu penelitiannya pada tanggal 6 April -7 juni tahun 2021.

Pengambilan data penelitian ini menggunakan Teknik wawancara, observasi dan studi dokumen. Wawancara yang dilakukan adalah wawancara tidak terstruktur dimana peneliti memberikan pertanyaan langsung secara spontan tanpa mengacu pada beberapa pokok pertanyaan. Peneliti juga melakukan observasi dalam penelitian ini yaitu mengamati langsung proses pengolahan serta pelaporan data rekam medis di Klinik Utama Mutiara Cikutra.

\section{HASIL}

hasil dari analisis beban kerja petugas rekam medis di Klinik Utama Mutiara Cikutra dengan menggunakan metode analisis beban kerja kesehatan (ABK-Kes) yang bersumber dari permenkes RI Nomor 53 tahun 2012 tentang pedoman pelaksanaan analisis beban kerja di lingkungan kementrian kesehatan. Langkah - langkah dalam analisis beban kerja terdiri dari 6 (enam) langkah sebagai berikut;

Langkah pertama, menetapkan fasilitas pelayanan kesehatan (Fasyankes) dan jenis sumber daya manusia kesehatan (SDMK). Fasilitas pelayanan kesehatan (fasyankes) yakni Klinik Utama Mutiara Cikutra. Kelompok SDMK adalah tenaga keterapian medis dan jenis SDMK adalah petugas rekam medis.

Langkah kedua, menetapkan waktu kerja tersedia (WKT). Penetapan waktu kerja tersedia (WKT) dihitung selama kurun waktu 1 (satu) tahun. Berdasarkan PERMEN PAN-RB NO.26 tahun 2011 tentang pedoman perhitungan jumlah kebutuhan pegawai negri sipil yang tepat untuk daerah, jam kerja efektif (JKE) sebesar 1.200 jam per tahun atau setara dengan 72.000 menit pertahun baik 5 hari kerja atau 6 hari kerja.

Langkah ketiga, menetapkan komponen beban kerja dan norma waktu. penetapan komponen beban kerja dan norma waktu di Klinik Utama Mutiara Cikutra dihitung menggunakan stopwatch, sedangkan norma waktu tugas penunjang di dapat dari hasil wawancara kepada petugas rekam medis di Klinik Utama Mutiara Cikutra.

Langka keempat, Menghitung standar beban kerja (SBK) atau kuantitas pekerjaan setiap SDMK selama 1 tahun.

Langkah kelima, menghitung standar tugas penunjang (STP) dan Faktor Tugas Penunjang (FTP). Standar tugas penunjang (STP) merupakan suatu nilai yang didapat dari hasil pengali terhadap kebutuhan SDMK tugas pokok. Sedangkan faktor tugas 
penunjang (FTP) merupakan proporsi waktu yang digunakan untuk menyelesaikan setiap kegiatan per satuan waktu. Terdapat 3 tugas penunjang yang ditugaskan kepada petugas rekam medis di Klinik Mutiara Cikutra.

Langkah keenam, menghitung kebutuhan sumber daya manusia kesehatan (SDMK). Kebutuhan SDMK = capaian 1 thn $/$ standar beban kerja $*$ STP. Capaian 1 tahun di dapat dari perhitungan jumlah pasien yang berkunjung ke Klinik Mutiara Cikutra di mulai dari bulan April 2020 sampai dengan bulan April 2021. Data tersebut didapat dari laporan bulanan kunjungan pasien di Klinik Utama Mutiara Cikutra. Berdasarkan data sekunder dari laporan bulanan kunjungan, kunjungan dari setiap poli I Klinik Utama Mutiara Cikutra sejumlah 47.139 pada periode April 2020 hingga April 3032. Rata - rata kunjungan pasien perhari yatu 129 (seratus dua puluh Sembilan) pasien.

\section{Tabel 1. Beban Kerja dan Norma Waktu}

\begin{tabular}{|c|c|c|c|}
\hline No & Jenis Tugas & Kemampuan Beban Kerja & Norma Waktu \\
\hline \multirow[t]{7}{*}{1} & \multirow[t]{7}{*}{ Tugas Pokok } & $\begin{array}{l}\text { Input Harian Rekam Medis Rawat } \\
\text { Jalan }\end{array}$ & 0,47 menit/drm \\
\hline & & $\begin{array}{l}\text { Assembling, Analisis } \quad \text { Ketidak } \\
\text { Lengkapan, Dan Koding Rawat Inap }\end{array}$ & 2,00 menit/drm \\
\hline & & Penyimpanan DRM Ke Rak Filing & 0,40 menit/drm \\
\hline & & Koding Rawat Jalan & 0,15 menit/drm \\
\hline & & $\begin{array}{l}\text { Membuat Statistik Rawat Inap Rekam } \\
\text { Medis Pasien Pulang }\end{array}$ & 2,00 menit/drm \\
\hline & & $\begin{array}{l}\text { Menginput Pertelaan Retensi Rekam } \\
\text { Medis }\end{array}$ & 0,12 menit/drm \\
\hline & & Mengecek Mutu dan KPI & 0,39 menit/drm \\
\hline \multirow[t]{3}{*}{2} & \multirow[t]{3}{*}{ Tugas Penunjang } & Diklat & 120menit/bln \\
\hline & & Rapat & 720 menit/bln \\
\hline & & Bimbingan PKL & 2.880 menit/thn \\
\hline
\end{tabular}

Berdasarkan tabel 1 diatas dijelaskan bahwa beban kerja sebanyak tujuh tugas pokok dan tiga tugas penunjang petugas Rekam Medis di Klinik Utama Mutiara Cikutra, yang masing - masing norma waktu dari tugasnya didapat dari hasil perhitungan menggunakan stopwatch dan melalui wawancara kepada petugas rekam medis tersebut. Norma waktu merupakan rata - rata waktu yang dibutuhkan oleh SDMK untuk melaksanakan suatu kegiatan sesuai dengan standar pelayanan yang berlaku di fasyankes bersangkutan.

Tabel 2. Menetapkan Waktu Kerja Tersedia (WKT) dalam 1 tahun

\begin{tabular}{ccccccc}
\hline No & Kode & Komponen & Keterangan & Rumus & Jumlah & Satuan \\
\hline & A & B & C & D & E & F \\
\hline $\mathbf{1}$ & A & Hari Kerja & 5 hari kerja / mg & 52 minggu & 260 & $\mathrm{hr} / \mathrm{thn}$ \\
\hline $\mathbf{2}$ & B & Cuti Pegawai & peraturan & & 12 & $\mathrm{hr} / \mathrm{thn}$ \\
\hline
\end{tabular}


Clarissa Amalia Putri, Meira Hidayati : Analisis Kebutuhan Sumber Daya Manusia Petugas Rekam ....

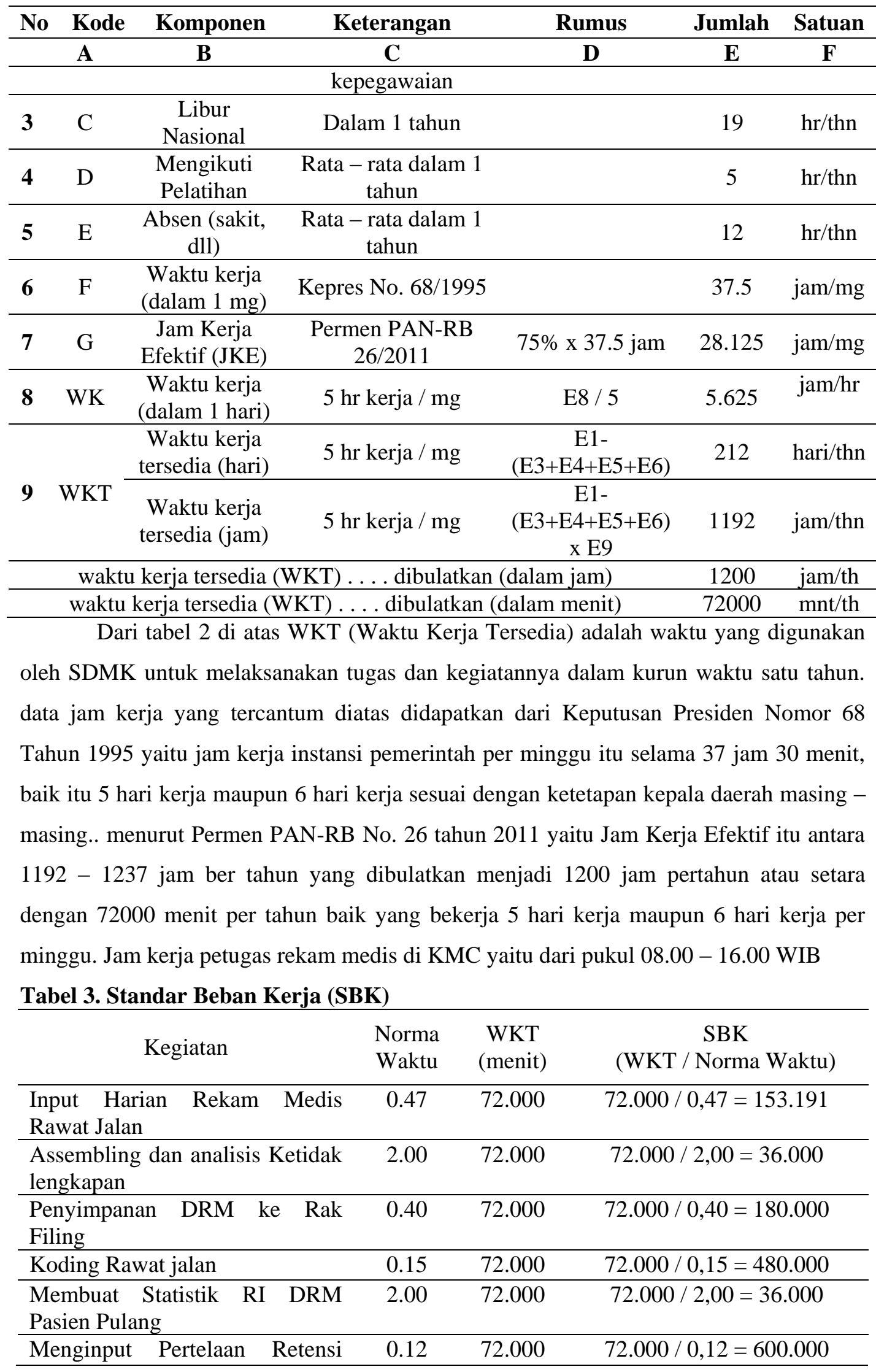




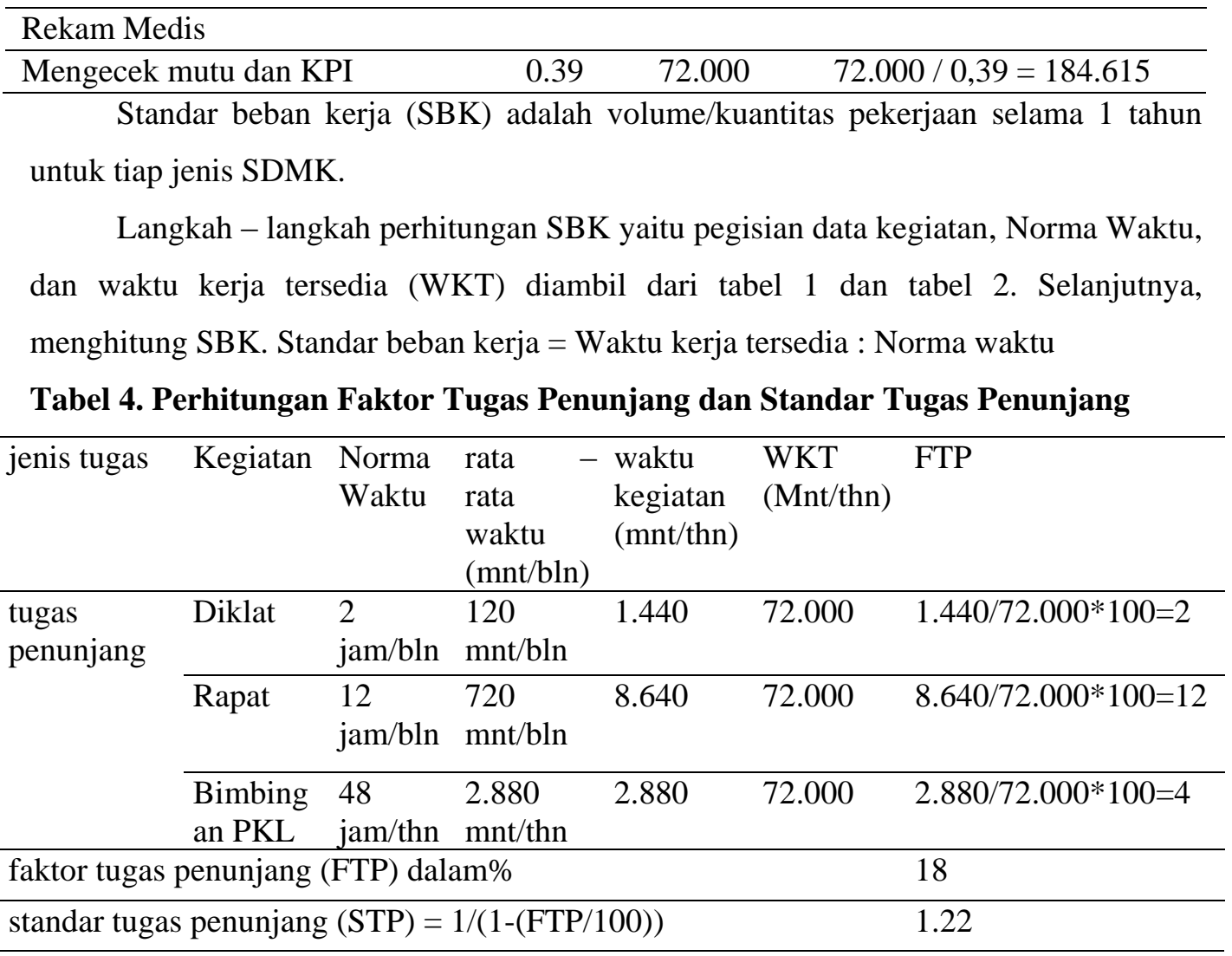

Tabel 4 merupakan tabel perhitungan faktor tugas penunjang sekaligus perhitungan standar tugas penunjang petugas rekam medis di Klinik Utama Mutiara Cikutra

Tabel 5. Kebutuhan Sumber daya Manusia Kesehatan Tugas Pokok

\begin{tabular}{|c|c|c|c|}
\hline Komponen Beban Kerja / Kegiatan & $\begin{array}{l}\text { Capaian } 1 \\
\text { th }\end{array}$ & SBK & Kebutuhan SDMK \\
\hline $\begin{array}{l}\text { Input Harian Rekam Medis Rawat } \\
\text { jalan }\end{array}$ & 47.139 & 153.191 & $\begin{array}{c}47.139 / 153.191 * \\
1,22=0,37\end{array}$ \\
\hline $\begin{array}{l}\text { Assembling dan analisis Ketidak } \\
\text { lengkapan }\end{array}$ & 47.139 & 36.000 & $\begin{array}{c}47.139 / 36.000 * 1,22 \\
=1,59\end{array}$ \\
\hline Penyimpanan DRM ke Rak Filing & 47.139 & 180.000 & $\begin{array}{r}47.139 / \\
1,22 \\
\end{array}$ \\
\hline Rawat jalan & 47.139 & 480.000 & $\begin{array}{c}47.139 / 480.000 * \\
1,22=0,12\end{array}$ \\
\hline $\begin{array}{l}\text { Membuat Statistik Rawat Rekam } \\
\text { Medis Pasien Pulang }\end{array}$ & 47.139 & 36.000 & $\begin{array}{c}47.139 / 36.000 * 1,22 \\
=1,60\end{array}$ \\
\hline $\begin{array}{lll}\text { Menginput } & \text { Pertelaan } & \text { Retensi } \\
\text { Rekam Medis } & & \\
\end{array}$ & 47.139 & 600.000 & $\begin{array}{c}47.139 / 600.000 * \\
1,22=0,09\end{array}$ \\
\hline Mengecek mutu dan KPI & 47.139 & 184.615 & $\begin{array}{c}47.139 / 184.615 * \\
1.22=0,31\end{array}$ \\
\hline
\end{tabular}

Pada tabel 5. Didapatkan data sebagai berikut. 
Clarissa Amalia Putri, Meira Hidayati : Analisis Kebutuhan Sumber Daya Manusia Petugas Rekam ....

JKT (Jumlah Kebutuhan Tenaga) Tugas Pokok = 4,43

Standar Tugas Penunjang (hasil dari langkah ke-5) $=1,22$

Total kebutuhan SDMK prtugas Rekam Medis di Klinik Utama Mutiara Cikutra yaitu :

Total kebutuhan SDMK $\quad=\quad($ JKT $*$ STP $)$

$=\quad 4,4 * 1,22$

$=\quad 5,368($ dibulatkan menjadi 5)

Tabel 6. Rekapitulasi SDMK Berdasarkan Metode ABK-kes

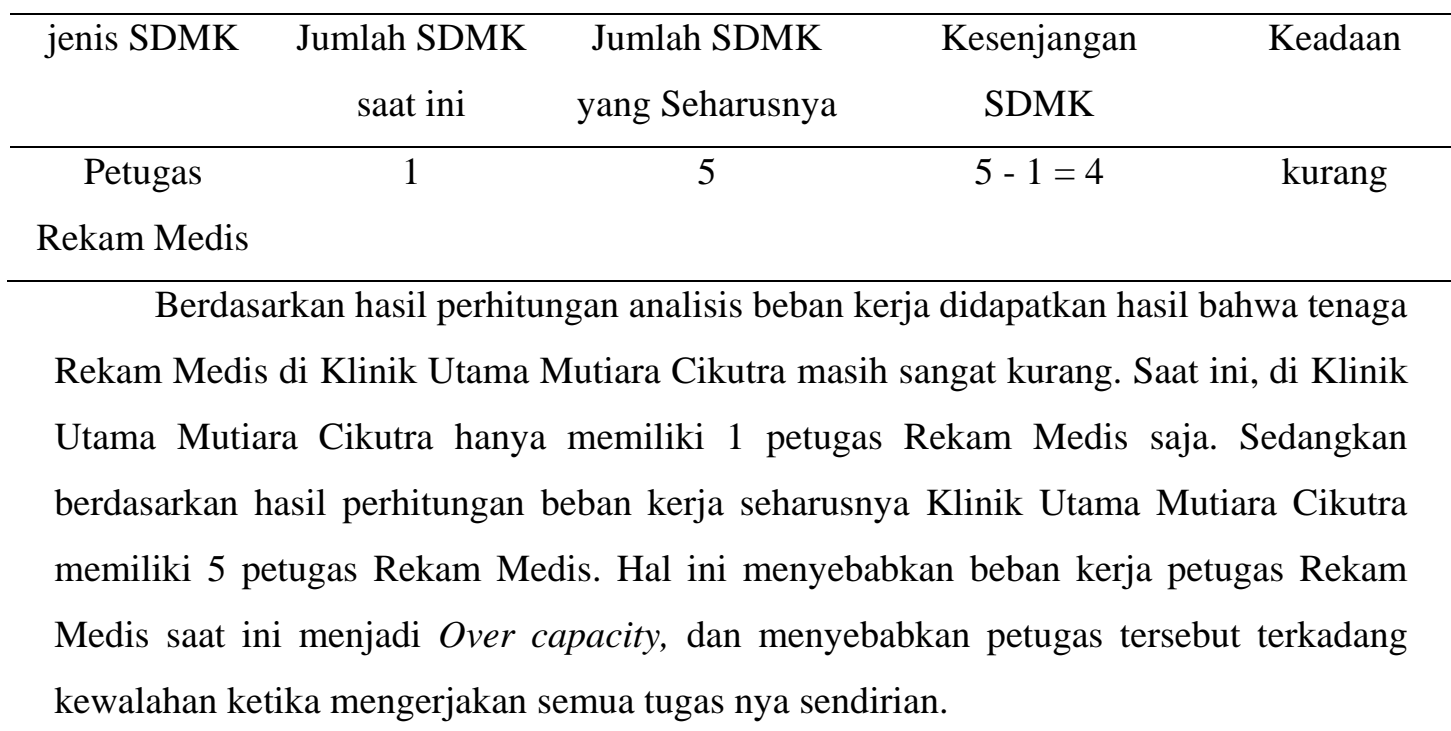

\section{PEMBAHASAN}

Beberapa penelitian yang terkait dengan penelitian yang saya lakukan ini telah dilakukan dalam menganalisis kebutuhan sumber daya manusia petugas rekam medis menggunakan metode analisis beban kerja kesehatan (abk-kes) di setiap fasyankes. Salah satu hasil penelitian yang terkait adalah penelitian (Chrismawanti, 2020) yaitu terdapat kesenjangan pemenuhan jumlah SDM pada unit rekam medis yaitu di bagian pendaftaran, assembling, dan koding hal tersebut diketahui dari hasil perhitungan yang dilakukan dengan metode analisis beban kerja kesehatan (abk-kes). Penambahan sumber daya manusia di bagian tersebut guna meningkatkan kualitas kinerja petugas rekam medis di tiap - tiap bagiannya.

Metode ABK-Kes terdiri dari 6 langkah yang dilakukan yaitu menetapkan fasyankes dan jenis SDMK, menetapkan waktu kerja tersedia (WKT), menetapkan komponen beban kerja dan norma waktu, menghitung standar beban kerja (SBK), menghitung standar tugas penunjang (STP) dan faktor tugas penunjang (FTP), dan menghitung kebutuhan sumber daya manusia kesehatan (SDMK). 
Waktu Kerja Tersedia (WKT) adalah waktu yang digunakan oleh SDMK untuk melaksanakan tugas dan kegiatannya dalam kurun waktu satu tahun. WKT yang saya ambil berdasarkan dari Keputusan Presiden Nomor 68 Tahun 1995 yaitu jam kerja instansi pemerintah per minggu itu selama 37 jam 30 menit, baik itu 5 hari kerja maupun 6 hari kerja sesuai dengan ketetapan kepala daerah masing - masing. Menurut PAN-RB No. 26 tahun 2011 Jam Kerja Efektif nya itu adalah 1200 jam per tahun atau setara dengan 72000 menit per tahun selama 5 hari kerja atau 6 hari kerja per minggu. Hasil penelitian yang saya lakukan Jam kerja petugas rekam medis di KMC yaitu dari pukul 08.00 - 16.00 WIB atau setara dengan 40 jam per minggu dimana jam kerja petugas rekam medis tersebut melebihi dari jam yang telah di tetapkan dalam Kepres Nomor 68 tahun 1995 yaitu 37 jam 30 menit per minggu.

Menurut Undang - Undang Kesehatan No.36 Tahun 2009. Beban kerja ialah hasil kali antara jumlah pekerjaan dengan waktu serta besaran pekerjaan yang wajib dipikul oleh sesuatu jabatan/unit organisasi. Tiap pekerja bisa bekerja tanpa membahayakan dirinya sendiri serta warga di sekelilingnya, sehingga harus dilakukan penyerasian antara beban kerja, kapasitas kerja serta area kerja untuk mendapatkan produktivitas kerja yang maksimal. Hasil dari penelitian serta wawancara kepada petugas rekam medis di KMC yang berada pada tabel 1 diatas dengan 7 tugas pokok serta 3 tugas penunjang dengan norma waktu tugas pokoknya $\leq 2$ menit serta tugas penunjangnya < 9.000 menit/tahun, dapat disimpulkan bahwa beban kerja petugas rekam medis tersebut melebihi jumlah pekerjaan yang seharusnya.

Berdasarkan data Rekapitulasi kebutuhan Sumber Daya Manusia Kesehatan (SDMK) diatas dengan metode ABK-Kes diketahui bahwa tenaga Rekam Medis di Klinik Utama Mutiara Cikutra terdapat kesenjangan pemenuhan dan membutuhkan bantuan tenaga rekam medis baru untuk meningkatkan kualitas dan kecepatan kerja guna meningkatkan mutu pelayanan serta peningkatan kinerja dari tenaga rekam medis di Klinik Utama Mutiara Cikutra.

\section{SIMPULAN}

Berdasarkan hasil penelitian ini dapat di tarik kesimpulan bahwa Klinik Utama Mutiara Cikutra memerlukan penambahan petugas Rekam Medis untuk meningkatkan kualitas pelayanan dan pelaporan bulanan. Dari perhitungan penulis dengan menggunakan metode Analisis beban kerja kesehatan (ABK-Kes) didapatkan hasil bahwa 
petugas rekam medis di Klinik Utama Mutiara Cikutra mendapatkan beban kerja yang sangat berat. Beban kerja yang berat ini dapat memberikan dampak atau pengaruh terhadap kualitas mutu pelayanan. Satu orang petugas rekam medis yang bekerja di KMC mendapatkan beban kerja sebanyak 7 tugas pokok serta 3 tugas penunjang dengan waktu kerja tersedia nya yaitu 72.000 menit/jam dengan 5 hari kerja. Hasil perhitungan kebutuhan sumber daya manusia kesehatan dengan menggunakan metode analisis beban kerja kesehatan (ABK-Kes) jumlah SDMK yang di butuhkan sebanyak 5 (lima) orang petugas rekam medis sedangkan SDMK yang ada pada saat ini hana 1 (satu) orang petugas rekam medis saja. Maka terdapat kesenjangan SDMK sebanyak 4 (empat) orang, untuk menutupi kesenjangan SDMK tersebut maka Klinik Utama Mutiara Cikutra harus menambah 4 pegawai baru untuk menyeimbangkan beban kerja, mempercepat proses penyelesaian pekerjaan, serta untuk peningkatan kinerja petugas rekam medis dan untuk meningkatkan mutu pelayanan kesehatan. Dengan adanya penambahan pegawai tersebut maka Klinik harus menambah jumlah unit komputer guna menunjang efisiensi dan efektifitas kerja petugas rekam medis tersebut.

\section{UCAPAN TERIMA KASIH}

Ucapan terimakasih penulis sampaikan kepada 1) Kedua Orang tua penulis yang telah memberikan dana dan doa dalam proses pembuatan jurnal ini, 2) kepada segenap civitas akademik program studi Rekam Medis dan Informasi Kesehatan Politeknik Piksi Ganesha Bandung, 3) kepada teman sahabat serta orang teristimewa yang selalu memberikan semangat kepada penulis.

\section{DAFTAR PUSTAKA}

Cahyaningrum, N., Noor, H. L., Anggita, R., \& Dewati, H. (2018). Tinjauan Beban Kerja Dan Kebutuhan Sumber Daya Manusia Unit Rekam Medis Berdasarkan Metode Wisn Di Rsui Banyu Bening Boyolali. Jurnal Ilmiah Rekam Medis Dan Informatika Kesehatan, 8(2), 40-54.

Chrismawanti, M. (2020). Tinjauan Kebutuhan Sumber Daya Manusia Di Rekam Medis Berdasarkan Metode Analisis Beban Kerja Kesehatan (Abk-Kes) Di Rumah Sakit Umum Darmayu Ponorogo. Jurnal Delima Harapan, 7(1), 48-57. Https://Doi.Org/10.31935/Delima.V7i1.95

Damara, D., \& Rahmatiqa, C. (2020). Analisis Beban Kerja Tenaga Filling Rekam Medis (Studi Kasus Klinik Medika Saintika). Jurnal Kesehatan Medika Saintika, 11(1), 27. https://doi.org/10.30633/jkms.v11i1.519

Ermanus, G., \& Jannah, L. (2018). Unit Kerja Rekam Medis Planning Of Human Resorce Reuiment On Service Of Medical Record Work. Program Studi Perekam Dan Informasi Kesehatan, 1(377), 8-9. 
Gultom, S. P., \& Sihotang, A. (2019). Analisa Kebutuhan Tenaga Rekam Medis Berdasarkan Beban Kerja Dengan Metode Wisn Di Bagian Pendaftaran Rumah Sakit Umum Haji Medan Tahun 2018. Jurnal Ilmiah Perekam Dan Informasi ..., 1, 524532.

Hikmah, F., Wijayanti, R. A. W., \& Laksono, M. J. C. (2019). Desain Formulir Asesmen Nyeri Dalam Berkas Rekam Medis Di Rumah Sakit Daerah Balung Jember Tahun 2016. Jurnal Kesehatan, 5(3), 138-148.

Keputusan Presiden Nomor 68 Tahun 1995 Tentang Hari Kerja Di Lingkungan Lembaga Pemerintah

Nawangwulan, S. (2018). Analisis Kebutuhan Pelatihan Dan Pengembangan Sumber Daya Manusia. Jurnal Manajemen Kesehatan Yayasan Rs.Dr. Soetomo, 4(1), 24. Https://Doi.Org/10.29241/Jmk.V4i1.98

Rakhmawati, F., \& Rustiyanto, E. (2016). Analisis Kebutuhan Petugas Rekam Medis Berdasarkan Beban Kerja Di Instalasi Rekam Medis Rs Aisyiah Muntilan. Jurnal Kesehatan Vokasional, 1(1), 1. Https://Doi.Org/10.22146/Jkesvo.27446

Ritonga, Z. A. (2017). Analisis Sumber Daya Manusia Terhadap Beban Kerja Di Bagian Penyimpanan Rekam Medis Menggunakan Metode Wisn (Workload Indicator Of Staffing Need) Di Rumah Sakit Umum Pusat H. Adam Malik Medan. Jurnal Ilmiah Perekam Dan Informasi Kesehatan Imelda, 2(1), 170-177.

Situmorang, C. V. (2017). Analisis Pengaruh Pengembangan Sumber Daya Manusia Terhadap Prestasi Kerja Karyawan: Studi Kasus Pada Sebuah Badan Usaha Milik Negara. Jurnal Kewiraushaan, 3(2), 50-58.

Suryanto, H. (2020). Analisis Beban Kerja Dan Kebutuhan Sumber Daya Manusia Petugas Rekam Medis Puskesmas Adan-Adan Kabupaten Kediri. Jurnal Rekam Medis Dan Informasi Kesehatan, 3(1), 29-35. Https://Doi.Org/10.31983/Jrmik.V3i1.5514

Talib, T. (2018). Analisis Beban Kerja Tenaga Filing Rekam Medis (Studi Kasus Rumah Sakit Ibu Dan Anak Bahagia Makassar). Jurnal Manajemen Informasi Kesehatan Indonesia, 6(2), 123. Https://Doi.Org/10.33560/.V6i2.196

Peraturan Menteri Kesehatan Republik Indonesia Nomor 028/Menkes/Per/I/2011 Tentang Klinik

Peraturan Menteri Kesehatan Republik Indonesia Nomor 55 Tahun 2013 tentang Penyelenggaraan Pekerjaan Perekam Medis

Peraturan Menteri Pendayagunaan Aparatur Negara dan Reformasi Birokrasi Nomor 26 tahun 2011 tentang Pedoman Perhitungan Jumlah Kebutuhan Pegawai Negeri Sipil Untuk Daerah

Peraturan Mentri Kesehatan Republik Indonesia Nomor 53 Tahun 2012 Tentang Pedoman Pelaksanaan Analisis Bebean Kerja Di Lingkungan Kementrian Kesehatan

Undang - Undang Kesehatan No.36 Tahun 2009 tentang Kesehatan

Undang.Undang Republik Indonesia Nomor 36 Tahun 2014 Tentang Tenaga Kesehatan

\begin{tabular}{|l|l|}
\hline Submission & $25-06-2021$ \\
\hline Review & $29-06-2021$ \\
\hline Accepted & $15-09-2021$ \\
\hline Publish & $29-10-2021$ \\
\hline DOI & $10.29241 /$ jmk.v7i2.637 \\
\hline Sinta Level & 3 (Tiga) \\
\hline
\end{tabular}

